\title{
Remote sensing and past climatic changes in tropical deserts: Example of the Sahara
}

In the last $20 \mathrm{ka}$, the tropical arid belt in the north of Africa underwent wide changes in its latitudinal range due to changes in atmospheric circulation fitting global changes. During the last glacial maximum, the desert extended down to $13^{\circ} \mathrm{N}$. During the last climatic optimum, it was replaced by sahelian environments up to $22^{\circ}-23^{\circ} \mathrm{N}$., and numerous lakes or swamps were observed in the field throughout all extant Sahara. Remote sensing allows an extensive reconstitution of these major paleoenvironmental changes and usefully supplements local field research.

\section{Introduction}

The rough covariation of changes in global parameters (insolation, ice volume, sea surface temperatures and atmospheric ratios of $\mathrm{CO}_{2}$ and $\mathrm{CH}_{4}$ ) during the last $150 \mathrm{ka}$, at least, also grossly matches the considerable changes in atmospheric circulation during this time.
This is particularly the case regarding monsoonal activity and the range of the extant tropical deserts relative to their current margins.

In the last 10 years, evidence has been brought from the Atlantic Ocean to the Gulf of Oman of extensions of the desert belt toward the Equator during cold phases and regressions of the same toward the Tropic of Cancer during warm phases. Geological and paleobiological records of past environmental changes show that shifts of the saharo-sahelian limit reached nearly $1,000 \mathrm{~km}$ in latitude between the last two extreme (cold-warm) scenarios of extreme cold and extreme warmth at $20 \mathrm{ka}$ and $8 \mathrm{ka}$, respectively (Petit-Maire, 1986, 1990, 1991; Pachur and Hoelzmann, 1991; and International Geological Correlation Programme Project 252 (Past and Future Evolution of Deserts) reports for 1987-1992).

The ground truth is matched and confirmed by remotely sensed synoptic evidence that fills the large gaps between the local terrestrial observations. An example will be given for the relative extensions of the Sahara and Sahel during these last cold and warm phases.

\section{The late Pleistocene}

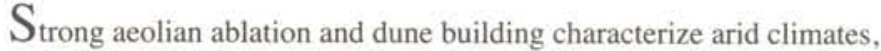
and the limit of active dunes roughly corresponds to the $150-\mathrm{mm}$ isohyet (Mainguet and others, 1980).

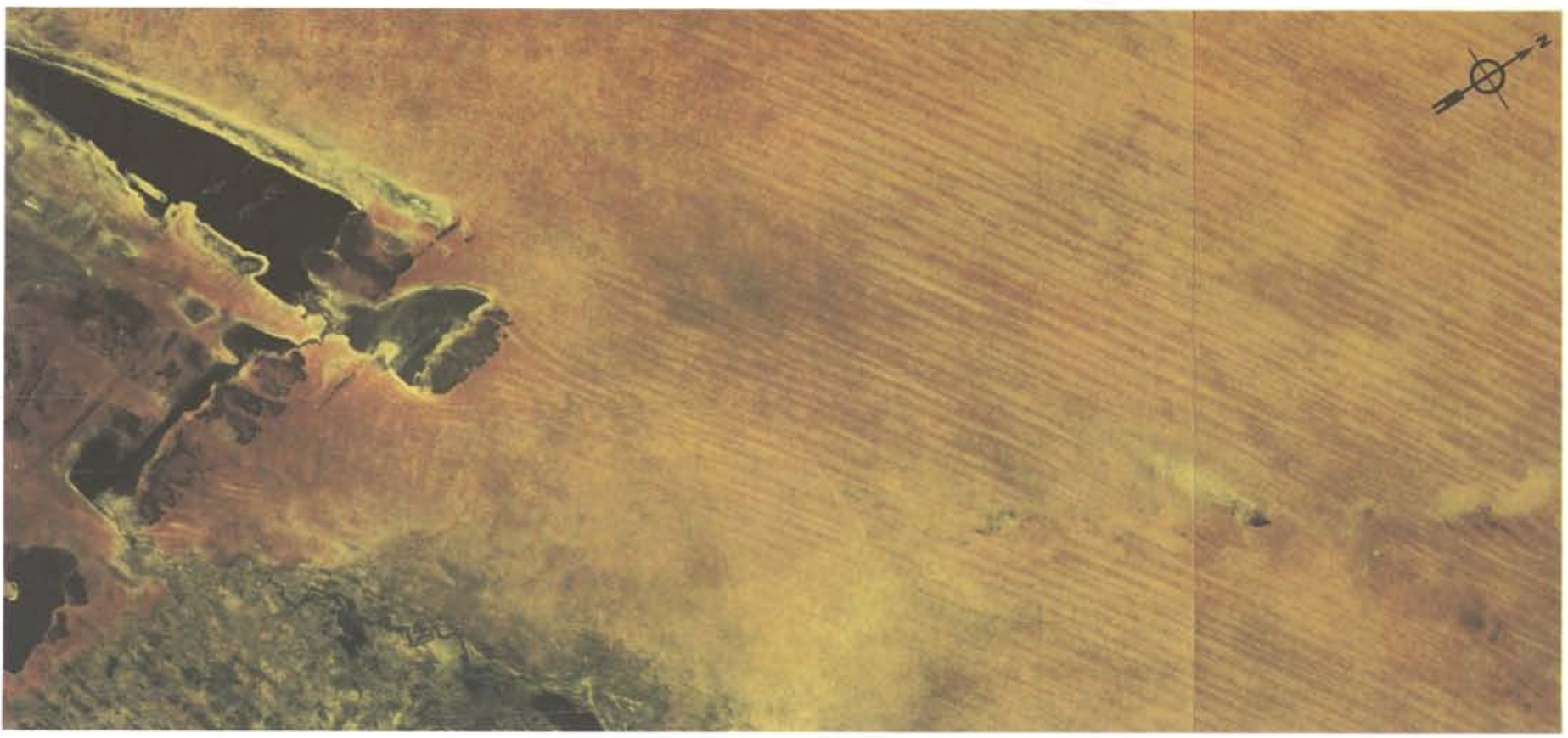

Figure 1.-Late Pleistocene longitudinal dunes north and south of the River Niger near Tombouctou, Mali, at 17 N. (Space image SLA-58242 courtesy of Gordon Wells, Lunar and Planetary Institute, Houston, Texas, USA.) 


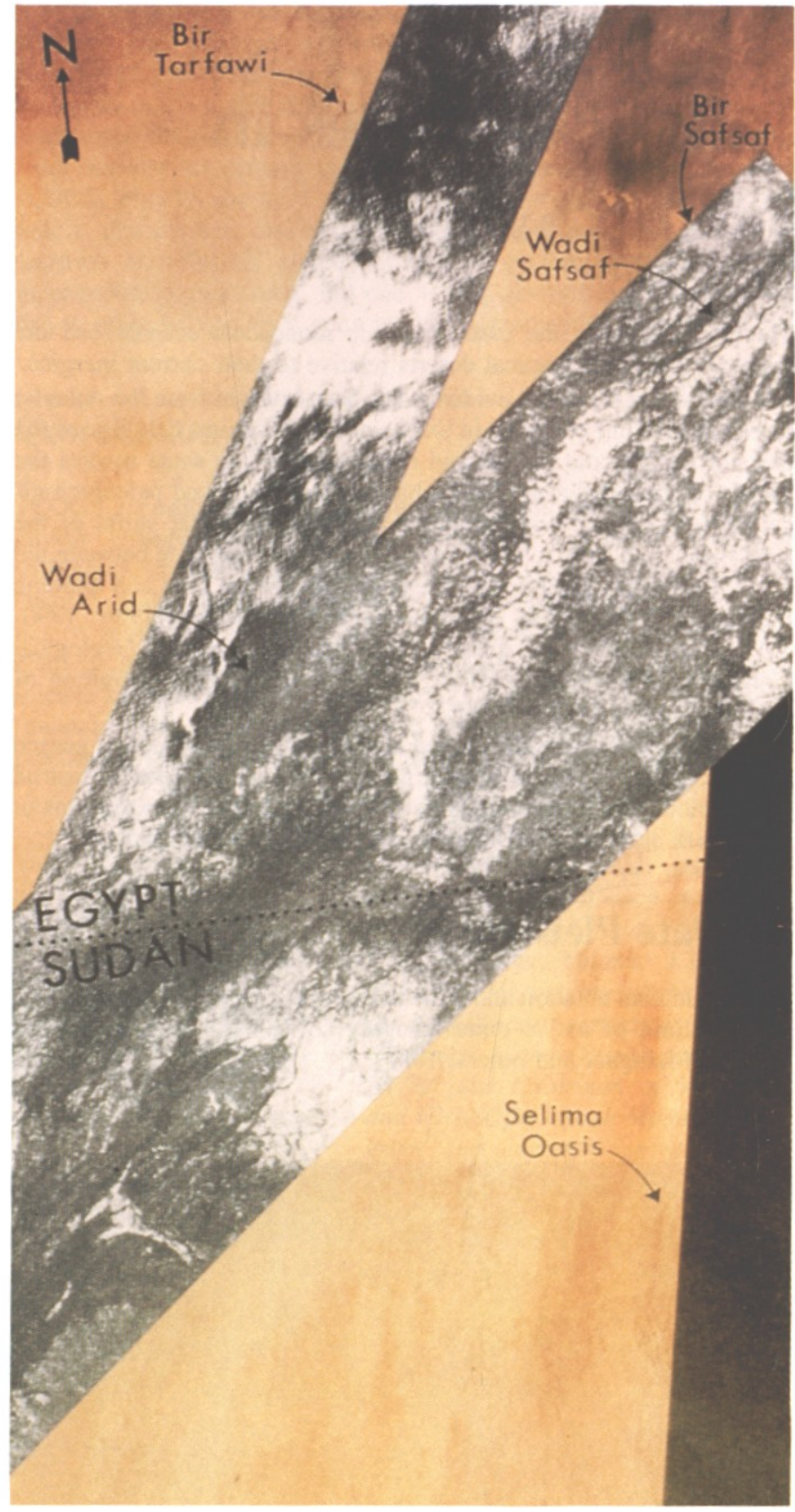

Figure 2. - "Radar rivers" in the hyperarid core of eastern Sahara at the border between Egypt and Sudan. The image is a composite of the USA's Shuttle Imaging Radar experiments $A$ and $B$ (SIR-A and B) and Landsat Multispectral Scanner (MSS). (Courtesy of J.F. McCauley and C.S. Breed, U.S. Geological Survey, Flagstaff, Arizona, USA.)

Field research has shown that the large, longitudinal, active ergs in the southern Sahara are underlain by similar, consolidated, reddish sands. These reddish sands were deposited during the late Pleistocene cold phase according to thermoluminescence dating (Smith and others, 1990), which testifies that the dominant wind direction at that time was similar to today's direction of $215^{\circ}-230^{\circ}$ (Fabre and Mainguet, 1984). This late Pleistocene erg system, now fixed and vegetated, extends over the Sahel some $300 \mathrm{~km}$ south of the extant

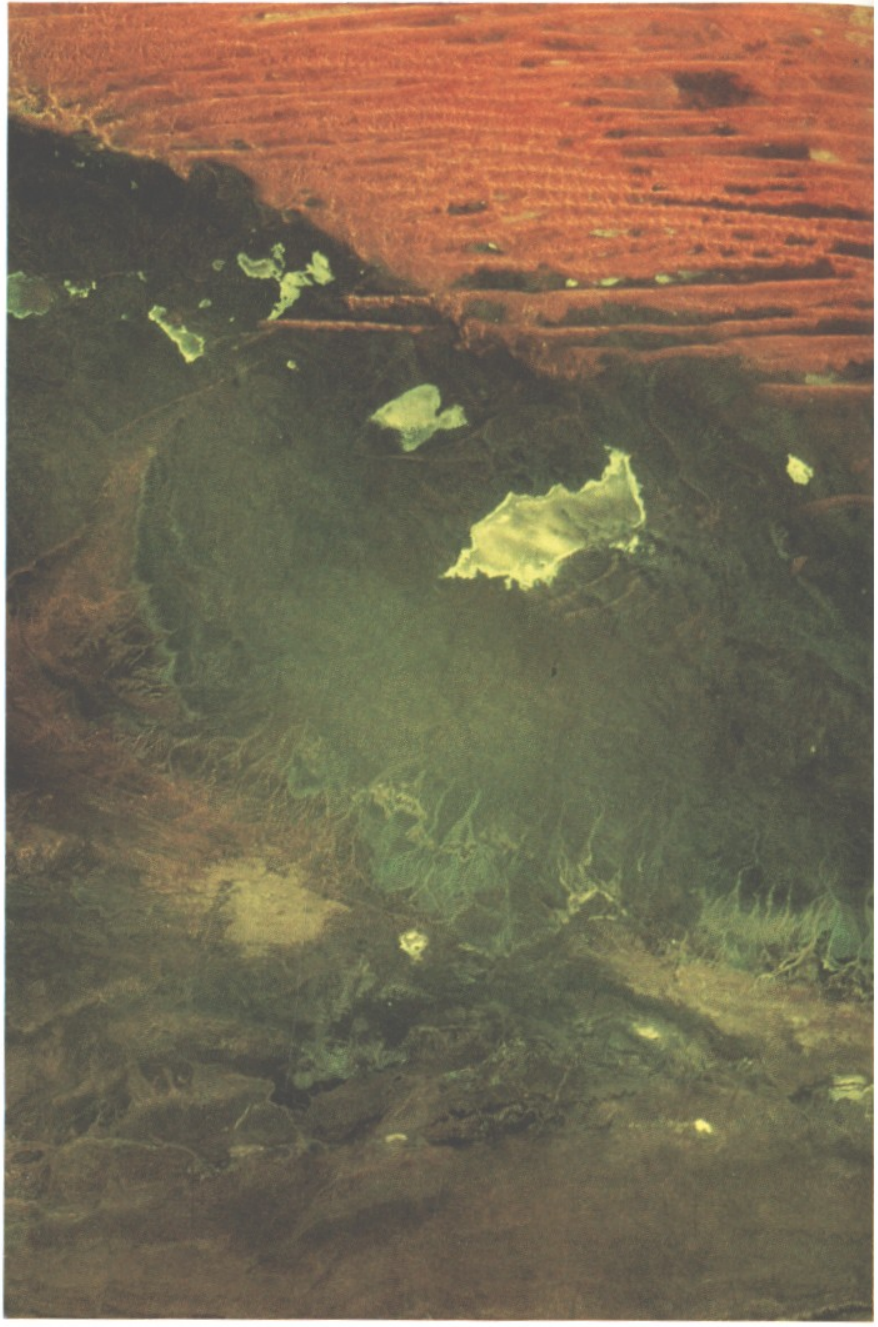

Figure 3. - String of paleolacustrine evaporitic deposits on the southern border of Erg Chech $\left(24^{\circ} 8^{\prime} \mathrm{N}\right.$., $5^{\circ} 16^{\prime} \mathrm{W}$.) showing faintly visible channel connections. (Space image SL4-76176 courtesy of Gordon Wells, Houston, Texas, USA.)

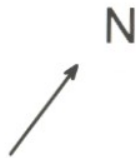

Sahara limit (Mainguet and others, 1980; Talbot, 1984; Ousseini and Morel, 1989), which proves the former extension of the arid belt during the late Pleistocene.

Aerial photographs already have shown the local extension of these erg structures, but space imagery now allows us to connect this whole aeolian system throughout the Sahara and Sahel. In relation with the cold global scenario, these observations imply strong, rapid and long-acting winds, similar to those currently sweeping over the Sahara, as well as annual rainfall less than $150 \mathrm{~mm}$ and the consequently scarce vegetal cover. These factors resulted in the construction of oriented sandy formations several hundreds of kilometers long throughout today's semiarid area. An example from northern Mali (fig. 1) at $17^{\circ} \mathrm{N}$., the current boundary between the Sahara and the Sahel, shows late Pleistocene ergs that extend widely in the direction of the dominant trade winds (northeast to southwest) and that cross the River Niger into the present interior delta. A large Holocene channel having lacustrine extensions is clearly visible cutting through the dunes to the northeast. The combination of ground truth and 

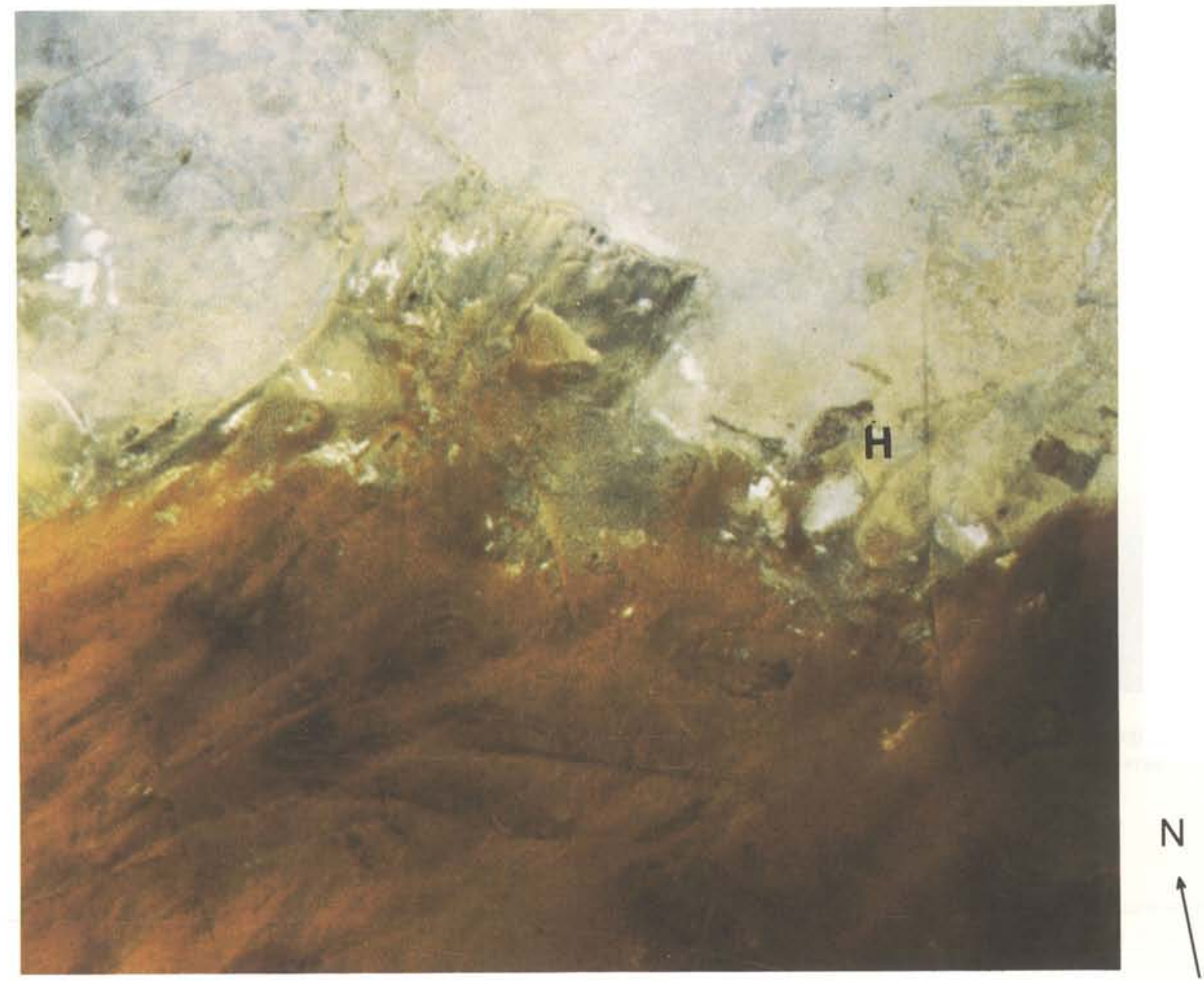

Figure 4. - Taoudenni area, Mali, at $22^{\circ} 50^{\prime}-23^{\circ} \mathrm{N}$. and $3^{\circ} 50^{\prime}-4^{\circ} \mathrm{W}$. The high reflectance of a string of carbonate lake sediments differs from the reflectance of the Cretaceous limestone plateau to the north (top of image) and from that of the Carboniferous sandstone and current sand sheets to the south. Dikes clearly command the lacustrine extension. Abbreviation: H, Haijad paleolake. (SPOT image 44-305, May 6, 1986.)

space imagery analysis resulted in precise paleogeographical mapping of this approximately $40,000-\mathrm{km}^{2}$ area (Petit-Maire and Riser, 1987, 1988).

\section{The Holocene optimum}

More than 1,000 radiocarbon dates on geological and paleobiological material sampled throughout the Sahara have brought evidence of major environmental change from east to west during the Holocene climatic optimum. In particular, most topographical depressions and the interdune troughs of the late Pleistocene ergs, considered before, were occupied by lakes or swamps that resulted from local precipitation and aquifer rise, even in today's hyperarid areas that have less than 5-mm mean annual rainfall (Petit-Maire, 1986; PetitMaire and others, 1990; Pachur and Hoelzmann, 1991).

Because of the vastness of the desert and the difficult access to its hyperarid cores, the past extent of surface fresh water cannot be known wholly through field research. Therefore, space imagery is a unique tool that can be used to complete our ground observations on the basis of already established image and ground-truth comparisons. However, the problems relative to large desert basins are the presence of tropospheric dust or of sand storms and the extension of recent surficial sand sheets that cover the earlier geologic features. Paleodrainage systems consequently are undetectable not only in surface research and aerial photographs but also in multispectral analysis. However, radar imagery clearly detects the paleochannels. A striking example is the work performed in the years 1982-1988 by McCauley and others (1982, 1986) on southern Egypt (fig. 2). Field investigations confirmed their initial interpretations of the radar images and produced geological and archeological evidence (McHugh and others, 1988) of paleoriver valleys, now buried under sand sheets, lined with prehistoric sites ranging in age from $0.5 \mathrm{Ma}$ to the Holocene optimum. The high potential of radar imagery for defining ancient drainage patterns in arid areas is thus remarkable, and this technique may possibly be used in association with past human 


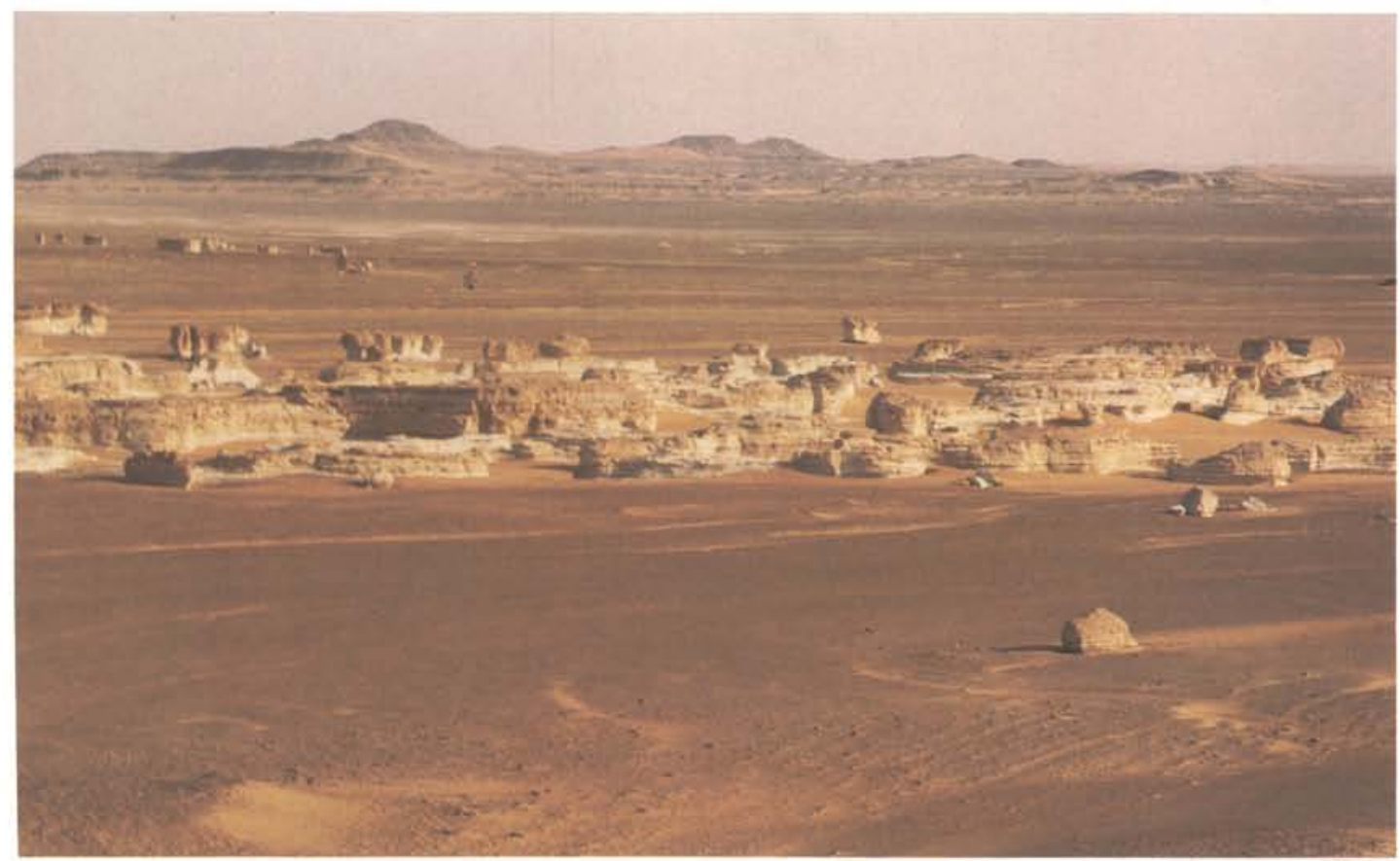

Figure 5.-In the center of a $65 \mathrm{~km}^{2}$ depression, fossiliferous carbonate deposits, 6 to $10 \mathrm{~m}$ high, now dissected by aeolian erosion, still testify to the existence of a Holocene paleolake. (Photograph by the author.)

occupation. One can imagine that these patterns may be used in the future for planning desert development and irrigation along special networks in which clays or paleosols may be found at little depth under the sand sheets.

Paleolakes or swamps are often quite visible in space imagery on account of their high-reflectance evaporitic (salt, gypsum, carbonate) surfaces (fig. 3). A coupled study in northern Mali (Petit-Maire, 1991) enhanced the use of remote sensing for the identification and study of paleolakes. A first teleanalysis of French SPOT images along a $150-\mathrm{km}$-long depression at $22^{\circ} 50^{\prime} \mathrm{N}$. (fig. 4) was based on the spectral signature of objects, despite a weak radiometry (Page and others, 1991). The color composite images clearly distinguish the Quaternary deposits from the rocks of the older series. The large structural features (dikes) in the area are particularly helpful to our understanding the location of the lacustrine deposits between these natural dams. Whereas ground truth (fig. 5) does not allow us to determine exactly the limits of the paleolacustrine extension, SPOT analysis allows us to evaluate their maximal surface. The paleoshorelines appear fairly clear after digital processing, although the slight sloping of the margins of the depressions often results in difficult mapping. Moreover, the scarce vegetation allowed by the present $5-\mathrm{mm}$ mean annual rainfall, which lines the subterranean drainage network but cannot be separated from rocky blocks on aerial photographs, is easily distinguishable on space imagery and thus traces the subsurface hydrographic system.

In conclusion, the interpretation of space images in tropical deserts is a great asset for paleoclimatic research and is, therefore, of major importance to studies of global change.

\section{References}

Fabre, J., and Mainguet, M., 1984, L'ablation éolienne en climat hyperaride: son rôle dans la genèse de la dépression de Taoudenni (Mali): Comptes Rendus des Séances de l'Académie des Sciences, série 2, v. 299, no. 13. p. $887-892$.

Mainguet, M., Canon, L., and Chemin, M.C., 1980, Le Sahara; géomorphologie et paléogéomorphologie éoliennes, in Williams, M.A.J., and Faure, H., eds., The Sahara and the Nile: Quaternary environments and prehistoric occupation in northern Africa: Rotterdam, A.A. Balkema Publishers, p. $17-35$.

McCauley, J.F., Breed, C.S., Schaber, G.G., McHugh, W.P., Issawi, B., Haynes, C.V., Grolier, M.J., and El Kilani, A., 1986, Paleodrainages of the eastern Sahara; the radar rivers revised (SIR-A/B implications for a mid-Tertiary trans-African drainage system): IEEE [Institute of Electrical and Electronics Engineers] Transactions on Geoscience and Remote Sensing, v. GE- 24 , no. 4 , p. $624-648$.

McCauley, J.F., Schaber, G.G., Breed, C.S., Grolier, M.J., Haynes, C.V., Issawi, B., Elachi, C., and Blom, R., 1982, Subsurface valleys and geoarcheology of the eastern Sahara revealed by Shuttle radar: Science, v. 218 , no. 4576, p. $1004-1020$.

McHugh, W.P., McCauley, J.F., Haynes, C.V., Breed, C.S., and Schaber, G.G., 1988, Paleorivers and geoarchaeology in the southern Egyptian Sahara: Geoarchaeology, v. 3, no. 1, p. 1-40.

Ousseini, I., and Morel, A., 1989, Utilisation de formations alluviales azoïque pour l'étude des paléoenvironnements du Pléistocêne supérieur et de I'Holocène au Sud du Sahara; I'exemple de la vallée du fleuve Niger dans le Liptake nigérien: Bulletin de la Société Géologique de France, serie 8 , v. 5, no. I. p. 85-90. 
Pachur, H.J., and Hoelzmann, P., 1991, Paleoclimatic implications of late Quaternary lacustrine sediments in western Nubia, Sudan: Quaternary Research, v. 36 , p. $257-276$.

Page, N., Simon, B., and Fabre, J., 1991, Apport des images SPOT à l'étude de la région de Taoudenni (Mali), in Petit-Maire, N., ed., Paléoenvironnements du Sahara: Lacs holocènes à Taoudenni (Mali): Marseille, Paris, Editions Centre National de la Recherche Scientifique, p. 65-69.

Petit-Maire, N., 1986, Paleoclimates in the Sahara of Mali: A multidisciplinary study: Episodes, v. 9, no, 1, p. 7-16.

1990, Will greenhouse green the Sahara? Episodes, v. 13, no. 2, p. 103-107.

ed., 1991, Paléoenvironnements du Sahara: Lacs holocènes à Taoudenni (Mali): Marseille, Paris, Editions Centre National de la Recherche Scientifique, 239 p.

Petit-Maire, N., Commelin, D., Fabre, J., and Fontugne, M., 1990, First evidence for Holocene rainfall in the Tanezrouft hyperdesert and its margins: Palaeogeography, Palaeoclimatology, Palaeoecology, v. 79 . nos. 3-4, p. 333-338.

Petit-Maire, N., and Riser, J., 1987, Holocene palaeohydrography of the Niger: Palaeoecology of Africa and of the Surrounding Islands, v. 18, p. 135-141.

-1988, Le Sahara à l'Holocène: Mali: Paris, Commission de la Carte Géologique du Monde, Institut Geographique National, 1 map, scale $1: 1,000,000$.

Smith, B.W., Rhodes, E.J., Stokes, S., Spooner, N.A.Z., and Aitken, M.J., 1990, Optical dating of sediments: Initial quartz results from Oxford: Archaeometry, v. 32, p. 19-31.

Talbot, M.R., 1984. Late Pleistocene rainfall and dune building in the Sahel: Palaeoecology of Africa and of the Surrounding Islands, v. 16, p. 203-214. D

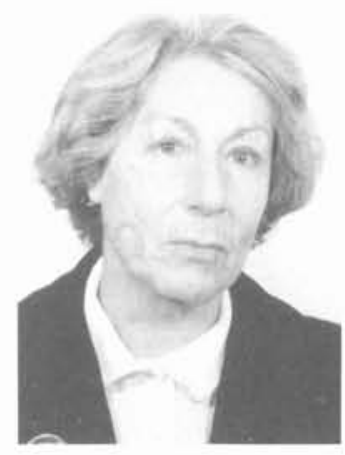

Dr. Nicole Petit-Maire, a Director of Research at Centre National de la Recherche Scientifique, France, has been working in the world deserts. mainly the Sahara, over the last 20 years, specializing in field research of past environmental change across the most desolate hyperarid areas. She is one among the first international scientists who probed, and realized with a large team of specialists in earth and biological sciences, multidisciplinary studies of continental climatic variations and who related her regional conclusions with global change. Since 1987, she has led IGCP Project 252 (Deserts: Past, Present, Future) and was elected one of the Vice Presidents of IUGS during the last International Geological Congress in Washington, D.C., USA. 